\title{
PENTINGNYA PERLINDUNGAN HUKUM KEKAYAAN INTELEKTUAL BAGI PEMBANGUNAN EKONOMI INDONESIA
}

\author{
Niru Anita Sinaga \\ Fakultas Hukum, Universitas Dirgantara Marsekal Suryadarma, Jakarta \\ Email: anita_s1naga@yahoo.com
}

Diterima : 17 Ags 2020 | Direvisi : 17 Sep 2020| Disetujui : 25 Sep 2020| Diterbitkan : 14 Des 2020

\begin{abstract}
The economic development of a country is closely related to the protection of its Intellectual Property. The higher the state's appreciation of intellectual property, the more it will stimulate economic growth. Intellectual property is a right arising from the results of thinking to produce a useful product or process. In essence, intellectual property is the right to enjoy economically the results of an intellectual creativity. Indonesia has a very strong commitment to the protection of Intellectual Property both nationally, regionally and internationally. This can be seen by: Formation of a National Law on Intellectual Property, namely: Copyrights, Trademarks and Geographical Indications, Patents, Industrial Designs, Layout Designs of Integrated Circuits, Protection of Plant Varieties and Trade Secrets; Take part in the ASEAN Frame work Agreement and Asia-Pacific Economic Cooperation (APEC) in the Osaka work agenda; Being a member of the World Trade Organization (WTO) implies that Indonesia is automatically bound to TRIPs; Ratified the World Intellectual Property Organization (WIPO). The establishment of an Intellectual Property Law must continue to have an orientation to the national interest while still observing international provisions. Protection of Intellectual Property Law in Indonesia adheres to the theory of justice based on Pancasila, with the principles: Humanity; Balance of individual and community interests; Nationalism; Social justice and the development of science and technology (science and technology) are not value free (based on the values of Pancasila). Although various regulations in the field of Intellectual Property have been established and enforced, there are still many problems. This is influenced by various factors, including: Relating to the substance, structure and culture (culture) of law. This research discusses: How is the implementation of intellectual property law protection for Indonesia's economic development and what problems are found in the implementation of intellectual property law protection for Indonesian economic development. The method used is normative juridical. To solve this problem, it is necessary to have a solution so that what is the goal of protecting Intellectual Property law is the realization of justice.
\end{abstract}

Keywords: Legal Protection, Intellectual Property, Economic Development

\begin{abstract}
ABSTRAK
Pembangunan ekonomi suatu negara berkaitan erat dengan perlindungan Kekayaan Intelektualnya. Semakin tinggi penghargaan negara terhadap Kekayaan Intelektual, akan merangsang pertumbuhan ekonomi. Kekayaan intelektual adalah hak yang timbul dari hasil olah pikir untuk menghasilkan suatu produk atau proses yang bermanfaat. Pada intinya kekayaan intelektual adalah hak untuk menikmati secara ekonomis hasil dari suatu kreativitas intelektual. Indonesia memiliki komitmen yang sangat kuat terhadap perlindungan Kekayaan
\end{abstract}


Intelektual baik yang bersifat nasional, regional maupun internasional. Hal ini dapat dilihat dengan: Dibentuknya Undang-Undang Nasional di bidang Kekayaan Intelektual, yaitu tentang: Hak Cipta, Merek Dan Indikasi Geografis, Paten, Desain Industri, Desain Tata Letak Sirkuit Terpadu, Perlindungan Varietas Tanaman dan Rahasia Dagang; Ikut ambil bagian dalam Persetujuan/Perjanjian Kerangka Kerja ASEAN (ASEAN Frame work Agreement) dan Asia-Pacific Economic Cooperation (APEC) dalam agenda kerja Osaka; Menjadi anggota Organisasi Perdagangan Dunia World Trade Organization (WTO) menyiratkan bahwa Indonesia secara otomatis terikat pada TRIPs; Meratifikasi World Intellectual Property Organization (WIPO). Pembentukan hukum Kekayaan Intelektual harus tetap memiliki orientasi pada kepentingan nasional dengan tetap memperhatikan ketentuan-ketentuan internasional. Perlindungan hukum Kekayaan Intelektual di Indonesia berpegang pada teori keadilan yang berdasarkan pada Pancasila, dengan prinsip-prinsip: Kemanusiaan; Keseimbangan kepentingan individu dan masyarakat; Nasionalisme; Keadilan sosial dan Pengembangan ilmu pengetahuan dan teknologi (iptek) tidak bebas nilai (berdasarkan nilainilai Pancasila). Meskipun telah dibentuk dan diberlakukan berbagai peraturan di bidang Kekayaan Intelektual, masih terdapat banyak permasalahan-permasalahan. Hal ini dipengaruhi berbagai faktor, antara lain: Berkaitan dengan substansi, struktur, dan budaya (kultur) hukum. Penelitian ini membahas tentang: Bagaimana pelaksanaan perlindungan hukum Kekayaan Intelektual bagi pembangunan ekonomi Indonesia dan Permasalahan apa saja yang ditemukan dalam pelaksanaan perlindungan hukum Kekayaan Intelektual bagi pembangunana ekonomi Indonesia. Metode yang digunakan adalah yuridis normatif. Untuk mengatasi permasalahan tersebut, maka dibutuhkan adanya solusi agar tercipta apa yang menjadi tujuan dari perlindungan hukum Kekayaan Intelektual yaitu terwujudnya keadilan.

Kata Kunci: Perlindungan Hukum, Kekayaan Intelektual, Pembangunan Ekonomi

\section{PENDAHULUAN}

Pembangunan ekonomi suatu negara sangat berkaitan erat dengan perlindungan Kekayaan Intelektualnya. Semakin terbuka sistem perekonomian suatu negara, maka perlindungan Kekayaan Intelektual akan memainkan peranannya dalam mendukung pembangunan ekonomi negara tersebut. Manusia dalam memenuhi segala kebutuhan dan kelangsungan hidupnya menggunakan kemampuan intelektual, ilmu pengetahuan dan teknologi. Intelektual merupakan hasil karya luhur manusia dalam mengadaptasikan dirinya dengan kehidupan nyata. Manusia mempunyai kemampuan intelektual yang berbeda antara satu dengan yang lainnya. Dalam lingkup yang lebih besar, suatu bangsa mempunyai derajat yang berbeda dalam hal kemampuan intelektual dengan bangsa lainnya. Dengan adanya perbedan kemampuan dibidang intelektualnya maka manusia itu saling membutuhkan satu sama lain. Dalam pergaulan yang demikian dibutuhkan aturan untuk melindungan semua pihak yang terlibat, antara lain tentang Kekayaan Intelektual.

Kekayaan Intelektual adalah hak yang timbul dari hasil olah pikir yang menghasilkan suatu produk atau proses yang berguna untuk manusia. Kekayaan Intelektual adalah hak eksklusif yang diberikan suatu hukum atau peraturan kepada seseorang atau sekelompok orang atas karya ciptanya. Pada intinya kekayaan Intelektual adalah hak untuk menikmati secara ekonomis hasil dari suatu kreativitas intelektual. Objek yang diatur dalam Kekayaan Intelektual berupa karya-karya yang timbul atau lahir karena kemampuan intelektual manusia. Kekayaan Intelektual telah menjadi bagian penting dalam perkembangan perekonomian nasional maupun international sebagai penggerak ekonomi. Untuk itu perlu pendekatan yang seimbang 
terhadap sistem kekayaan intelektual global untuk pelindungan, pemajuan, dan pemanfaatan Kekayaan Intelektual bagi pembangunan ekonomi nasional.

Pertumbuhan ekonomi Indonesia dan dunia sangat ditopang oleh Kekayaan Intelektual yang selalu tumbuh dan berkembang seiring komersialisasi Kekayaan Intelektual tersebut. Oleh karenanya, diharapkan karya intelektual bangsa selalu dapat tumbuh dan berkembang serta dapat berharmonisasi dengan karya intelektual bangsa lain. Tumbuhnya konsepsi kekayaan atas karya-karya intelektual membutuhkan perlindungan hukum terhadap Kekayaan Intelektual tersebut.

Indonesia sebagai negara berkembang perlu memajukan sektor ekonomi dengan meningkatkan kemampuan daya saing. Salah satu daya saing tersebut adalah dengan memanfaatkan peranan Kekayaan Intelektual. Keanekaragaman budaya yang dipadukan dengan upaya untuk ikut serta dalam globalisasi perdagangan, dengan memberikan pula perlindungan hukum terhadap Kekayaan Intelektual akan mempercepat pembangunan ekonomi. Mengingat hal-hal tersebut, Indonesia perlu membuat regulasi untuk menjamin perlindungan Kekayaan Intelektual dan menetapkan hak dan kewajibannya serta menjaga agar pihak yang tidak berhak tidak menyalahgunakan hak Kekayaan Intelektual tersebut. Selain mewujudkan komitmen terhadap Persetujuan TRIPs, pengaturan Kekayaan Intelektual dimaksudkan untuk memberikan landasan bagi perlindungan yang efektif terhadap berbagai bentuk pelanggaran-pelanggaran di bidang Kekayaan Intelektual. Perlindungan hukum Kekayaan Intelektual dimaksudkan untuk merangsang aktivitas kreatif untuk terusmenerus menciptakan karya-karya yang baru. Perlindungan hukum Kekayaan Intelektual diberikan oleh negara Republik Indonesia melalui prosedur yang telah ditentukan dalam peraturan-peraturan yang telah ditentukan. Ketentuan tersebut diperlukan sebagai sikap penghargaan, penghormatan dan perlindungan untuk memberikan rasa aman dan mewujudkan iklim yang kondusif bagi peningkatan semangat atau gairah untuk menghasilkan karya-karya inovatif, inventif dan produktif.

Dasarnya Kekayaan Intelektual adalah hak untuk menikmati secara ekonomis hasil dari suatu kreativitas intelektual, dimana objek yang diatur adalah karya-karya yang timbul atau lahir karena kemampuan intelektual manusia dengan kecerdasan, kemampuan berpikir, berimajinasi, atau hasil dari proses berpikir manusia atau the creation of human mind. Perlindungan hukum dapat dijadikan sebagai jaminan untuk menghargai karya-karya di bidang Kekayaan Intelektual, sehingga lebih giat lagi memikirkan ide yang akan dituangkan ke dalam kegiatan yang menghasilkan karya. Semakin tinggi penghargaan negara terhadap Kekayaan Intelektual, maka perekonomian juga akan meningkat dan masa depan suatu bangsa akan menjadi lebih baik. Hal ini juga sejalan dengan prinsip bahwa Kekayaan Intelektual merupakan suatu alat untuk meraih dan mengembangkan ekonomi.

Perkembangan pasar bebas dalam dunia perdagangan dalam dasawarsa terakhir ini sangat pesat pertumbuhannya. Pasar memberi peluang kepada masyarakat untuk memperdagangkan barang dan jasa. Dalam melakukan kegiatan perdagangan, baik domestik maupun antar negara sangat berpengaruh terhadap Kekayaan Intelektual. Masyarakat pelaku usaha membutuhkan campur tangan pemerintah melalui undangundang untuk mengatur persaingan usaha yang tidak sehat, agar dalam situasi kompetitif seperti sekarang tidak terjadi aspek-aspek negatif dimana pelaku usaha yang memiliki modal kuat, berpengalaman, terampil dan cepat berkembang, tidak total menguasai pasar yang dapat menghalangi tumbuh dan berkembangnya pelaku usaha kecil untuk maju. ${ }^{1}$

\footnotetext{
${ }^{1}$ Suhasril dan Mohammad Taufik Makarao, Hukum Larangan Praktik Monopoli dan Persaingan Usaha
} Tidak Sehat di Indonesia, Bogor: Ghalia Indonesia, 2010, hal. vii. 
Perlindungan hukum Kekayaan Intelektual yang efisien dalam pasar global telah menjadi fenomena ekonomi, sehingga semua negara-negara di dunia termasuk Indonesia untuk mengikutinya. Globalisasi ekonomi yang juga semakin dikembangkan oleh prinsip liberalisasi perdagangan (trade liberalization) atau perdagangan bebas (free trade) lainnya, telah membawa pengaruh pada hukum setiap negara yang terlibat dalam globalisasi ekonomi dan perdagangan bebas tersebut. ${ }^{2}$ Arus globalisasi ekonomi dan perdagangan bebas sulit untuk ditolak dan harus diikuti karena globalisasi ekonomi dan perdagangan bebas berkembang melalui perundingan dan perjanjian internasional. ${ }^{3}$ Globalisasi ekonomi membawa implikasi terhadap globalisasi hukum dan hal ini tidak dapat dihindari karena globalisasi hukum mengikuti globalisasi ekonomi, hal mana substansi berbagai undang-undang dan perjanjian-perjanjian menyebar melewati batas-batas negara (cross-border). ${ }^{4}$

Indonesia sebagai salah satu negara yang memiliki komitmen yang sangat kuat terhadap perlindungan Kekayaan Intelektual sudah lama menerapkannya dengan terlibat secara aktif baik yang bersifat nasional, regional maupun internasional. Meskipun keikutsertaan tersebut masih belum dapat menghilangkan secara otomatis faktor-faktor penghalang didalam penegakan perlindungan hukum Kekayaan Intelektualnya. Namun setidaknya Indonesia telah berusaha menunjukkan kepada dunia internasional, bahwa Kekayaan Intelektual mempunyai peranan yang sangat penting dan harus dilindungi dalam pembangunan saat ini. Dalam menghadapi era perdagangan bebas dibutuhkan kesiapan, mengingat persetujuan Trade Related Aspects of Intellectual Property Rights (TRIPs)-WTO sudah efektif berlaku bagi semua negara anggota termasuk Indonesia. Indonesia harus berusaha agar tetap eksis dan dapat bersaing dalam era perdagangan bebas tersebut. Jika tidak dapat dipastikan Indonesia akan terpuruk dan jatuh dalam peraturan perdagangan Internasional. ${ }^{5}$

Indonesia sebagai negara berkembang giat membangun industrinya, baik yang berbasis sumber daya alam (SDA) maupun industri yang berbasis pengetahuan (knowledge based-industry) dan berbasis ekonomi kreatif (creative economy). Industri berbasis SDA ini pada prinsipnya akan sangat bergantung pada ketersediaan dari SDA itu sendiri. Apabila SDA tersebut pada akhirnya habis, maka akan membawa implikasi yaitu industri yang bergerak dibidang tersebut lambat laun akan berhenti dan mati dengan sendirinya. Berbeda dengan industri berbasis pengetahuan dan ekonomi kreatif $^{6}$ yang saat ini merupakan kebijakan dari Pemerintah Republik Indonesia, yang menitikberatkan pada sumber daya manusia (SDM). Pada industri berbasis pengetahuan dan ekonomi kreatif, yang menjadi aset penting dan mempunyai nilai ekonomi sangat tinggi adalah karya-karya intelektual yang dihasilkan oleh orangorang kreatif dan inovatif yang bergerak dan berkarya di dalam industri tersebut, baik secara perorangan atau beberapa orang atau badan hukum atau komunitas.

\footnotetext{
${ }^{2}$ Cita Citrawinda, dkk, Naskah Akademik Rancangan Undang-undang Tentang Desain Industri, Pusat Perencanaan Pembangunan Hukum Nasional Badan Pembinaan Hukum Nasional Kementerian Hukum dan Hak Asasi Manusia, 2013, hal,7 (bagian Pendahuluan)

${ }^{3}$ John Braithwaite dan Peter Drahos, Global Business Regulation, New York: Cambridge University Press, 2000, hal. 24-23.

4 Erman Rajagukguk, "Globalisasi Hukum dan Kemajuan Teknologi: Implikasinya Bagi Pendidikan Hukum dan Pembangunan Hukum Indonesia," pidato pada Dies Natalis Universitas Sumatera Utara Ke-44, Medan 20 Nopember 2001, hal. 4.

${ }^{5}$ Ranti Fauza Mayana, Perlindungan Desain Industri di Indonesia, Jakarta: Gramedia Widiasarana Indonesia, 2004, hal. 218

${ }^{6}$ Instruksi Presiden RI Nomor 6 Tahun 2009 tentang Pengembangan Ekonomi Kreatif. Kategori ke 15 adalah kuliner.
} 
Setiap sektor yang menghasilkan karya-karya intelektual yang mempunyai nilai ekonomi tinggi, berpeluang terjadinya perbuatan-perbuatan curang, antara lain: Pencurian atau pembajakan atas karya-karya tersebut. Untuk mencegahnya perlu adanya perlindungan terhadap Kekayaan Intelektual tersebut, baik melalui Hak Cipta, Paten, Rahasia Dagang, Merek dan bahkan Desain Industri. ${ }^{7}$ Kekayaan Intelektual mengalami perkembangan yang sangat pesat dan sangat bermanfaat, sehingga perlu mendapat perlindungan.

Perlindungan Kekayaan Intelektual di Indonesia dapat dilihat dengan dibentuknya Undang-Undang Nasional di bidang Kekayaan Intelektual, yaitu: Undang-undang Republik Indonesia Nomor 28 Tahun 2014 Tentang Hak Cipta; Undang-undang Republik Indonesia Nomor 20 Tahun 2016 Tentang Merek Dan Indikasi Geografis; Undang-undang Republik Indonesia Nomor 13 Tahun 2016 Tentang Paten; Undang-undang Republik Indonesia Nomor 31 Tahun 2000 Tentang Desain Industri; Undang-undang Republik Indonesia Nomor 32 Tahun 2000 Tentang Desain Tata Letak Sirkuit Terpadu; Undang-undang Republik Indonesia Nomor 29 Tahun 2000 Tentang Perlindungan Varietas Tanaman; Undang-undang Republik Indonesia Nomor 30 Tahun 2000 Tentang Rahasia Dagang.

Meskipun telah dibentuk dan diberlakukan berbagai peraturan yang mengatur bidang Kekayaan Intelektual, masih terdapat banyak permasalahan-permasalahan atau pelanggaran-pelanggaran. Permasalahan tersebut dipengaruhi berbagai faktor, antara lain: yang berkaitan dengan struktur hukum, substansi hukum, budaya hukum. Salah satu kendala dalam melakukan pembangunan di Indonesia khususnya di bidang ekonomi adalah faktor perangkat hukum yang masih perlu dikembangkan dan ditegakkan guna mengimbangi kebutuhan kemajuan masyarakat. ${ }^{8}$ Perangkat hukum yang belum memadai dapat mengakibatkan timbulnya dampak negatif dalam pelaksanaan pembangunan ekonomi tersebut. Misalnya dalam hal persaingan usaha yang tidak sehat di antara pelaku bisnis. Hal ini dapat menimbulkan sengketa di bidang Kekayaan Intelektual. Banyak terjadi kasus-kasus pelanggaran Kekayaan Intelektual yang merupakan salah satu bentuk persaingan tidak sehat berupa penjiplakan, pemalsuan, dan praktik-praktik tidak sehat lainnya. Tentu saja hal ini amat merugikan pemilik hak dan negara. ${ }^{9}$

Dengan menerapkan perlindungan Kekayaan Intelektual secara maksimal dapat memajukan sektor industri, dan ekonomi kreatif dapat meningkatkan kemampuan daya saing di pasaran internasional. Salah satu contohnya yang akan dirubah adalah dengan memudahkan persyaratan-persyaratan untuk mendapatkan haknya, penyesuaian sanksi dengan situasi saat ini terhadap pelanggaran yang terjadi sehingga bagi yang melanggar mempunyai efek jera terhadap perbuatannya. Perbaikan tersebut perlu dilakukan dengan komitmen yang kuat untuk memperbaiki segala kelemahan perlindungan Kekayaan Intelektual yang ada saat ini. Sehingga dengan adanya peraturan-peraturan yang baru diharapkan dapat memberikan perlindungan yang lebih efisien dalam proses dan efektif dalam implementasinya serta penegakan hukumnya. Dengan demikian diharapkan dengan sistem Kekayaan Intelektual yang baik dapat memajukan sektor industri, dan ekonomi kreatif dapat meningkatkan kemampuan daya saing di pasaran internasional. Hal ini sejalan dengan pendapat Lawrence $\mathbf{M}$.

\footnotetext{
${ }^{7}$ Cita Citrawinda, dkk, Op. Cit., hal. 8.

${ }^{8}$ Ranti Fauza Mayana, Op.Cit., hal. 1.

${ }^{9}$ Ibid, hal. 29.
} 
Friedman, yang mengatakan hukum itu tidak bersifat otonom, tetapi sebaliknya hukum bersifat terbuka setiap waktu terhadap pengaruh luar. ${ }^{10}$

Dengan latar belakang yang telah diuraikan diatas, penulis ingin mengetahui dan membahas lebih dalam tentang: Bagaimana pelaksanaan perlindungan hukum Kekayaan Intelektual bagi pembangunan ekonomi Indonesia dan Permasalahan apa saja yang ditemukan dalam pelaksanaan perlindungan hukum Kekayaan Intelektual bagi pembangunana ekonomi Indonesia dalam penelitian yang berjudul: "Pentingnya Perlindungan Hukum Kekayaan Intelektual Bagi Pembangunan Ekonomi Indonesia”.

\section{METODE PENELITIAN}

Penelitian ini menggunakan pendekatan yuridis normatif yaitu dengan menginventarisasi, mengkaji dan menganalisis serta memahami hukum sebagai perangkat peraturan atau norma-norma positif di dalam sistem perundang-undangan yang mengatur mengenai kehidupan manusia ${ }^{11}$. Spesifikasi Penelitian ini adalah penelitian deskriptif analitis yang merupakan penelitian untuk menggambarkan alur komunikasi ilmiah dan menganalisa masalah yang ada yang akan disajikan secara deskriptif. ${ }^{12}$ Jenis data yang digunakan adalah data sekunder. Data sekunder adalah antara lain mencakup bahan-bahan pustaka yang terkait penelitian, data sekunder mencakup: bahan hukum primer, bahan hukum sekunder dan bahan hukum tersier. Pengumpulan data dalam penelitian ini dilakukan melalui studi pustaka. Data dianalisis secara normatif-kualitatif.

\section{PEMBAHASAN}

\section{Kekayaan Intelektual Secara Umum}

Istilah hak atas kekayaan intelektual merupakan terjemahan dari istilah Intellectual Property Rights (Bahasa Inggris) dalam sistem hukum Anglo Saxon. Sedangkan istilah hak atas milik intelektual merupakan terjemahan dari istilah intellectuele eigendomsrecht (Bahasa Belanda) dalam sistem hukum Kontinental. ${ }^{13}$ Istilah HaKI atau Hak atas Kekayaan Intelektual merupakan terjemahan dari Intellectual Property Right (IPR), sebagaimana diatur dalam undang-undang No. 7 Tahun 1994 tentang pengesahan WTO (Agreement Establishing The World Trade Organization). Pengertian Intellectual Property Right sendiri adalah pemahaman mengenai hak atas kekayaan yang timbul dari kemampuan intelektual manusia, yang mempunyai hubungan dengan hak seseorang secara pribadi yaitu hak asasi manusia (human right). ${ }^{14}$

Di Indonesia istilah tentang Kekayaan Intelektual mengalami perubahan. Dasar Hukum Perubahan istilah HAKI Menjadi HKI, Kemudian KI adalah sebagai berikut: ${ }^{15}$

\footnotetext{
${ }^{10}$ Lawrence M. Friedman, Legal Cultur and the Welfare State: Law and Society-An Introduction, Cambridge, Massachusetts, London: Harvard University Press, 1990 , hal. 89.

${ }^{11}$ Soerjono Soekanto, Penelitian Hukum Normatif, Jakarta: PT Raja Grafindo Persada, 2003, hal. 13.

12 Ibid, hal. 30.

${ }^{13}$ Pipin Syarifin \& Dedah Jubaedah, Peraturan Hak Kekayaan Intelektual di Indonesia, Bandung: Pustaka Bani Quraisy, 2004, hal. 1.

14 https://www.duniadosen.com/hak-atas-kekayaan-intelektual-haki/, diakses 5 November 2020, pkl 07.01 WIB.

15 https://www.hukumonline.com/klinik/detail/ulasan/cl3290/dasar-hukum-perubahan-istilah-hakimenjadi-hki--kemudian-ki/, diakses 5 November 2020, pkl 07.01 WIB.
} 
Hak Atas Kekayaan Intelektual (HAKI) menjadi Hak Kekayaan Intelektual (HKI) merujuk pada artikel Perkembangan Sistem Perlindungan Hak Kekayaan Intelektual di Indonesia ${ }^{16}$. Dalam artikel tersebut ditulis antara lain bahwa:"Dilihat dari perkembangan hak kekayaan intelektual (HKI) di tanah air, sistem hukum (IPR) pertama kali diterjemahkan menjadi "Hak Milik Intelektual”, kemudian menjadi "Hak Milik Atas Kekayaan Intelektual". Istilah yang umum dan lazim dipakai sekarang adalah Hak Kekayaan Intelektual yang disingkat HKI. Hal ini sejalan dengan dikeluarkannya Surat Keputusan Menteri Hukum dan PerUndang-Undangan RI Nomor M.03.PR.07.10 Tahun 2000 dan Persetujuan Menteri Negara Pendayagunaan Aparatur Negara, dalam surat Nomor 24/M/PAN/1/2000 istilah "Hak Kekayaan Intelektual" (tanpa "Atas") dapat disingkat "HKI" atau akronim "HaKI" telah resmi dipakai. Jadi bukan lagi Hak Atas Kekayaan Intelektual (dengan "Atas"). Surat Keputusan Menteri Hukum dan PerUndang-Undangan tersebut didasari pula dengan Keputusan Presiden Republik Indonesia Nomor 144 Tahun 1998 tanggal 15 September 1998, tentang perubahan nama Direktorat Jenderal Hak Cipta, Paten dan Merek berubah menjadi Direktorat Jenderal Hak Atas Kekayaan Intelektual (Ditjen HAKI) kemudian berdasar Keputusan Presiden Nomor 177 Tahun 2000 Ditjen HAKI berubah menjadi Ditjen HKI."Jadi istilah Hak Atas Kekayaan Intelektual (HAKI) yang berubah menjadi HKI (Hak Kekayaan Intelektual) berdasarkan Pasal 8 huruf g Keputusan Presiden Nomor 177 Tahun 2000 tentang Susunan Organisasi dan Tugas Departemen.

Hak Kekayaan Intelektual (HKI) Menjadi Kekayaan Intelektual (KI). Sebagaimana yang sebelumnya diatur dalam Pasal 145 huruf f Peraturan Presiden Nomor 24 Tahun 2010 tentang Kedudukan, Tugas, dan Fungsi Kementerian Negara serta Susunan Organisasi, Tugas, dan Fungsi Eselon I Kementerian Negara ("Perpres 24/2010") disebutkan mengenai susunan organisasi eselon I Kementerian Hukum dan Hak Asasi Manusia yang salah satunya adalah Ditjen HKI. Namun dalam perkembangannya, Perpres 24/2010 tersebut telah dicabut keberlakuannya dengan Peraturan Presiden Nomor 44 Tahun 2015 tentang Kementerian Hukum dan Hak Asasi Manusia ("Perpres 44/2015"). Jika melihat ke dalam Bab II dengan judul Organisasi, Bagian Kesatu dengan judul Sub Bab Susunan Organisasi pada Pasal 4 huruf f Perpres 44/2015, disebutkan bahwa Kementerian Hukum dan Hak Asasi Manusia salah satunya terdiri atas Direktorat Jenderal Kekayaan Intelektual ("Ditjen KI"). Dapat disimpulkan bahwa telah terjadi perubahan istilah yang tadinya dalam Perpres 24/2010 adalah Ditjen HKI, diubah dalam Perpres 44/2015 menjadi Ditjen KI.

Kekayaan Intelektual sulit untuk didefinisikan, meskipun demikian, uraian mengenai Kekayaan Intelektual dapat digambarkan secara_umum. Sebagai contoh, hukum Kekayaan Intelektual dapat melindungi karya sastra dan karya artistik serta invensi dari penggunaan atau peniruan yang dilakukan oleh pihak lain tanpa $\operatorname{izin}^{17}$. Adapun Kekayaan Intelektual merupakan kekayaan atas segala hasil produksi kecerdasan daya pikir seperti teknologi, pengetahuan, seni, sastra, gubahan lagu, karya tulis, karikatur, dan lain-lain yang berguna untuk manusia. ${ }^{18}$ Kekayaan Intelektual adalah suatu hak yang timbul dari karya intelektual seseorang yang mendatangkan keuntungan materil. Keuntungan materil inilah yang dapat memberikan kesejahteraan

\footnotetext{
${ }^{16}$ Buletin Informasi dan Keragaman HKI yang diterbitkan oleh Direktorat Jenderal Hak Kekayaan Intelektual ("Ditjen HKI"), Vol. V/No.3/Juni 2008, hal. 11.

${ }^{17}$ Tim Lindsey, dkk, Asian Law Group Pty.Ltd, Hak Kekayaan Intelektual Suatu Pengantar, Bandung: PT. Alumni, 2011, hal. 2.

${ }^{18}$ Sutedi, A, Hak Atas Kekayaan Intelektual, Jakarta: Sinar Grafika, 2009, hal. 38.
} 
hidup bagi pemilik. Kekayaan Intelektual merupakan hak yang berasal dari hasil kegiatan kreatif kemampuan daya pikir manusia yang diekspresikan kepada khalayak umum dalam berbagai bentuk, yang bermanfaat dalam menunjang kehidupan manusia karena memiliki nilai ekonomis. Bentuk nyata dari kemampuan tersebut misalnya dalam bidang teknologi, ilmu pengetahuan, seni dan sastra. Kekayaan Intelektual adalah hak memperoleh perlindungan secara hukum atas kekayaan intelektual sesuai dengan peraturan perundang-undangan. Hak tersebut dapat digunakan/dimanfaatkan oleh manusia untuk meningkatkan kesejahteraan/kebahagiaan hidup. Kekayaan Intelektual juga dapat diartikan sebagai hak eksklusif yang diberikan suatu hukum atau peraturan kepada seseorang atau sekelompok orang atas karya ciptanya. Pada intinya Kekayaan Intelektual adalah hak untuk menikmati secara ekonomis hasil dari suatu kreativitas intelektual. Objek yang diatur dalam Kekayaan Intelektual adalah karya-karya yang timbul atau lahir karena kemampuan intelektual manusia ${ }^{19}$

\section{Tujuan Perlindungan Hukum Kekayaan Intelektual}

Banyak karya-karya yang lahir atau dihasilkan oleh manusia melalui kemampuan intelektualitasnya, baik melalui daya, rasa maupun karyanya. Perlindungan hukum terhadap hasil intelektual manusia seperti di bidang teknologi, ilmu pengetahuan, seni, sastra, dan lain-lain, perlu diperhatikan dengan serius. Sebab karya manusia ini telah dihasilkan dengan suatu pengorbanan tenaga, pikiran, waktu, bahkan biaya yang tidak sedikit. Pengorbanan demikian tentunya menjadikan karya yang dihasilkan memiliki nilai yang patut dihargai. Serta dengan karya-karya seperti itu tentunya memiliki nilai ekonomi yang tinggi. Dengan adanya konsepsi berpikir seperti di atas, timbul kepentingan untuk menumbuhkan dan mengembangkan sistem perlindungan hukum atas kekayaan (hak intelektualitas) tersebut. Sebagai karya yang dihasilkan dari intelektualitas manusia, Kekayaan Intelektual hanya dapat diberikan kepada pemilik intelektual untuk menikmati atau memetik manfaat orang guna melakukannya.

Setiap hak yang digolongkan ke dalam Kekayaan Intelektual harus mendapat kekuatan hukum atas karya intelektualnya. Untuk itu diperlukan tujuan penerapan perlindungan Kekayaan Intelektual. Tujuannya: Pertama, antisipasi kemungkinan melanggar Kekayaan Intelektual milik pihak lain, Kedua meningkatkan daya kompetisi dan pangsa pasar dalam komersialisasi Kekayaan Intelektual, Ketiga dapat dijadikan sebagai bahan pertimbangan dalam penentuan strategi penelitian, usaha dan industri di Indonesia. ${ }^{20}$ Sistem Kekayaan Intelektual merupakan hak privat (private rights). Seseorang bebas untuk mengajukan permohonan atau mendaftarkan karya intelektualnya atau tidak. Hak eklusif yang diberikan Negara kepada individu pelaku Kekayaan Intelektual (inventor, pencipta, pendesain dan sebagainya) tiada lain dimaksudkan sebagai penghargaan atas hasil karya atau kreativitasnya dan agar orang lain terangsang untuk dapat lebih lanjut mengembangkannya lagi, sehingga dengan sistem Kekayaan Intelektual tersebut kepentingan masyarakat ditentukan melalui mekanisme pasar. Disamping itu sistem Kekayaan Intelektual menunjang diadakannya sistem dokumentasi yang baik atas segala bentuk kreativitas manusia sehingga kemungkinan dihasilkannya teknologi atau karya lainnya yang sama dapat dihindari atau dicegah. Dengan dukungan dokumentasi yang baik tersebut, diharapkan masyarakat dapat memanfaatkannya dengan maksimal untuk keperluan hidupnya atau

19 Ditjen kekayaan intelektual, Buku Panduan Hak Kekayaan Intelektual,2006, hal. 7.

${ }^{20}$ https://www.duniadosen.com, Op., Cit. 
mengembangkannya lebih lanjut untuk memberikan nilai tambah yang lebih tinggi lagi. ${ }^{21}$

\section{Ruang Lingkup Kekayaan Intelektual}

Secara umum ruang lingkup Kekayaan Intelektual meliputi: Hak Cipta, Merek, Paten, Desain Industri, Desain tata letak Sirkuit terpadu, Rahasia Dagang, Perlindungan Varietas Tanaman (PVT).

Hak Cipta adalah hak eksklusif pencipta yang timbul secara otomatis berdasarkan prinsip deklaratif setelah suatu ciptaan diwujudkan dalam bentuk nyata tanpa mengurangi pembatasan sesuai dengan ketentuan peraturan perundang-undangan ${ }^{22}$

Merek adalah tanda yang dapat ditampilkan secara grafis berupa gambar, logo, nama, kata, huruf, angka, susunan warna, dalam bentuk 2 (dua) dimensi dan/atau 3 (tiga) dimensi, suara, hologram, atau kombinasi dari 2 (dua) atau lebih unsur tersebut untuk membedakan barang dan/atau jasa yang diproduksi oleh orang atau badan hukum dalam kegiatan perdagangan barang dan/atau jasa. ${ }^{23}$

Paten adalah hak eksklusif yang diberikan oleh negara kepada inventor atas hasil invensinya di bidang teknologi untuk jangka waktu tertentu melaksanakan sendiri invensi tersebut atau memberikan persetujuan kepada pihak lain untuk melaksanakannya. ${ }^{24}$

Desain Industri adalah suatu kreasi tentang bentuk, konfigurasi, atau komposisi garis atau warna, atau garis dan warna, atau gabungan daripadanya yang berbentuk tiga dimensi atau dua dimensi yang memberikan kesan estetis dan dapat diwujudkan dalam pola tiga dimensi atau dua dimensi serta dapat dipakai untuk menghasilkan suatu produk, barang, komoditas industri, atau kerajinan tangan. ${ }^{25}$

Sirkuit Terpadu adalah suatu produk dalam bentuk jadi atau setengah jadi, yang di dalamnya terdapat berbagai elemen dan sekurang-kurangnya satu dari elemen tersebut adalah elemen aktif, yang sebagian atau seluruhnya saling berkaitan serta dibentuk secara terpadu di dalam sebuah bahan semikonduktor yang dimaksudkan untuk menghasilkan fungsi elektronik.

Desain Tata Letak adalah kreasi berupa rancangan peletakan tiga dimensi dari berbagai elemen, sekurang-kurangnya satu dari elemen tersebut adalah elemen aktif, serta sebagian atau semua interkoneksi dalam suatu Sirkuit Terpadu dan peletakan tiga dimensi tersebut dimaksudkan untuk persiapan pembuatan Sirkuit Terpadu. ${ }^{26}$

Varietas tanaman yang selanjutnya disebut varietas, adalah sekelompok tanaman dari suatu jenis atau spesies yang ditandai oleh bentuk tanaman, pertumbuhan tanaman, daun, bunga, buah, biji, dan ekspresi karakteristik genotipe atau kombinasi genotipe yang dapat membedakan dari jenis atau spesies yang sama oleh sekurangkurangnya satu sifat yang menentukan dan apabila diperbanyak tidak mengalami perubahan. ${ }^{27}$

Rahasia Dagang adalah informasi yang tidak diketahui oleh umum di bidang teknologi dan/atau bisnis, mempunyai nilai ekonomi karena berguna dalam kegiatan usaha, dan dijaga kerahasiaannya oleh pemilik Rahasia Dagang. ${ }^{28}$

\footnotetext{
21 Ibid

${ }^{22}$ Undang-undang Nomor 28 Tahun 2014 Tentang Hak Cipta, Pasal 1 angka 1.

${ }^{23}$ Undang-undang Nomor 20 Tahun 2016 Tentang Merek dan Indikasi Geografis., Pasal 1 angka1.

${ }^{24}$ Undang-undang Nomor 13 Tahun 2016 Tentang Paten, Pasal 1 angka1.

${ }^{25}$ Undang-undang Nomor 31 Tahun 2000, Tentang Desain Industri, Pasal 1 angka 1.

${ }^{26}$ Undang-undang Nomor 32 Tahun 2000, Tentang Desain Tata Letak Sirkuit Terpadu, Pasal 1 angka

1 dan 2.

${ }^{27}$ Undang-undang Nomor 29 Tahun 2000, Tentang Varietas Tanaman, Pasal 1 angka 3.

${ }^{28}$ Undang-undang Nomor 30 Tahun 2000, Tentang Rahasia Dagang, Pasal 1 angka 1.
} 


\section{Indonesia dan Pengaturan Internasional Kekayaan Intelektual}

Dewasa ini permasalahan perlindungan Kekayaan Intelektual tidak lagi menjadi urusan satu negara saja, tetapi sudah menjadi urusan masyarakat internasional. Untuk mewujudkan perlindungan Kekayaan Intelektual yang efisien, efektif dan menguntungkan semua anggota WTO, diperlukan adanya kerja sama antara anggota WTO baik yang bersifat regional maupun internasional. Sebagai salah satu negara yang memiliki komitmen yang sangat kuat terhadap perlindungan Kekayaan Intelektual, Indonesia juga sudah lama terlibat secara aktif dalam kerangka kerja baik yang bersifat regional maupun internasional di bidang Kekayaan Intelektual. Meskipun keikutsertaan tersebut tidak secara otomatis menghapus faktor-faktor penghalang di dalam penegakan Kekayaan Intelektual di Indonesia, setidaknya Indonesia telah menunjukkan kepada dunia internasional, bahwa Kekayaan Intelektual telah menjadi prioritas utama di dalam pembangunannya saat ini ${ }^{29}$.

\section{Pengaturan Internasional Kekayaan Intelektual}

Pengaturan internasional Kekayaan Intelektual adalah bagian yang tidak dapat dipisahkan dari sistem pengaturan Kekayaan Intelektual Indonesia. Standar Kekayaan Intelektual internasional telah menjadi sebuah sumber yang penting bagi hukum Kekayaan Intelektual Indonesia, dan sistem administrasi internasional memberikan sumbangan kepada sistem administrasi Kekayaan Intelektual di Indonesia. Indonesia juga telah menjadi peserta aktif dalam banyak pengembangan Kekayaan Intelektual internasional saat ini, khususnya melalui keikutsertaannya sebagai negara peserta dalam Organisasi Perdagangan Dunia (WTO) dan Organisasi Kekayaan Intelektual Dunia (WIPO). Peran serta Indonesia secara langsung dimulai sejak tahun 1950, beberapa tahun setelah kemerdekaan, saat Indonesia meratifikasi Konvensi Paris, sebuah perjanjian internasional di bidang hak kekayaan industri. Indonesia telah mengambil bagian di dalam Putaran Uruguay (1986-1994), yang merupakan salah satu rangkaian terakhir perundingan perdagangan multilateral. Menjadi peserta perundingan-perundingan Perjanjian Pendirian WTO yang salah-satu komponennya adalah (TRIPS). Perundingan Putaran Uruguay menetapkan sebuah paket komprehensif yang mencakup aturan-aturan perdagangan dan pembentukan WTO sebagai sebuah lembaga formal untuk administrasi dan perundingan lebih lanjut dari aturan-aturan yang telah dihasilkan. Indonesia adalah negara peserta pendiri (original member) Keanggotaan Indonesia pada WTO menyiratkan bahwa Indonesia secara otomatis terikat pada $\operatorname{TRIPS}^{30}$

\section{Unsur-Unsur Utama Dari Sistem Kekayaan Intelektual Internasional dan Regional}

Komitmen Indonesia terhadap mekanisme regional dan Internasional berkaitan dengan Kekayaan Intelektual meliputi: Keanggotaan aktif di WTO; diperkuat oleh ratifikasi konvensi pembentukan WIPO pada tahun 1979; Kepatuhan terhadap perjanjian-perjanjian internasional yang bersifat mendasar mengenai hukum Kekayaan Intelektual secara substantif yang dikelola oleh WIPO khususnya konvensi Paris tentang perlindungan kekayaan industri; Kepatuhan terhadap perjanjian internasional yang diselenggarakan oleh WIPO yang bersifat teknis, administratif dan fasilitatif; Keikutsertaan di dalam proses pembuatan kebijakan WIPO; Keikutsertaan di dalam

${ }^{29}$ Tim Lindsey, dkk, Asian Law Group Pty.Ltd, Op. Cit., hal. 23-24..

${ }^{30}$ Ibid, hal. 24-25 
kegiatan kerja sama regional; Kepatuhan terhadap instrumen-instrumen internasional mengenai permasalahan terkait dengan sistem Kekayaan Intelektual. ${ }^{31}$

\section{Latar Belakang Perjanjian TRIPs}

Dalam menegaskan, menerapkan, dan memperluas traktat-traktat utama WIPO, Persetujuan TRIPs membuat kesinambungan dengan hukum internasional yang berlaku secara universal. TRIPs merupakan tonggak penting dalam perkembangan standar-standar internasional dalam system Kekayaan Intelektual. TRIPs memiliki karakteristik yang berbeda, antara lain: Pengertian bahwa perlindungan Kekayaan Intelektual yang seimbang dan efektif merupakan suatu masalah perdagangan, dan untuk itu diarahkan ke dalam sebuah sistem aturan perdagangan multilateral yang lebih luas; Lingkup pengaturan hukum yang lebih menyeluruh, mencakup Hak Cipta, Hak Terkait, dan Kekayaan Industri dalam satu perjanjian internasional; Pengaturanpengaturan yang terinci mengenai penegakan dan administrasi Kekayaan Intelektual dalam sistem hukum nasional; Penggunaan mekanisme penyelesaian sengketa WTO, dan Pembuatan proses-proses yang transparan secara terstruktur untuk mendorong pemahaman yang lebih rinci dari hukum Kekayaan Intelektual nasional negara-negara anggota WTO. Pengaruh TRIPs bagi Indonesia telah dapat dirasakan, serta tidak dapat diragukan lagi telah menjadi pendorong utama di balik aktifnya kegiatan pembuatan perundang-undangan saat ini serta perkembangan mekanisme administrasi dan penegakan bidang Kekayaan Intelektual. ${ }^{32}$.

\section{Substansi TRIPs}

Sistem Kekayaan Intelektual dibentuk, diikat, dan dikelo untuk mencapai tujuan yang lebih luas, misalnya untuk: Menciptakan lingkungan yang kondusif bagi perdagangan dan investasi, khususnya yang berhubungan dengan alih teknologi dan produk-produk kreatif dan inovatif; Memberikan kontribusi bagi perkembangan teknologi, alih teknologi secara efektif dan peningkatan teknologi masyarakat asli; Mendorong perkembangan usaha-usaha yang memiliki nilai pembeda dan mempunyai daya saing internasional; Menyokong komersialisasi secara efektif terhadap penemuan-penemuan dan inovasi-inovasi milik masyarakat asli; Mendorong perkembangan sosial dan budaya, serta Memberi nilai tambah terhadap ekspor tradisional, dan melindungi reputasi ekspor di pasar internasional. ${ }^{33}$ TRIPS Pasal 7 menetapkan bahwa: ${ }^{34}$ Perlindungan dan penegakaan Kekayaan Intelektual seharusnya dapat memberikan kontnbusi dalam mendorong mendorong inovasi di bidang teknologi dan alihteknologi serta penyebaran teknologi, bagi keuntungan bersama baik bagi produser maupun pengguna ilmu teknologi dan dengan cara yang kondusif bagi kesejahteraan ekonomi dan sosial, serta pagi keseimbangan antara hak dan kewajiban. Untuk menggambarkan pengaruh isi pasal-pasal TRIPS terhadap hukum Indonesia, beberapa pembaharuan terhadap hukum Kekayaan Intelektual Indonesia telah menunjukkan penundukannya pada standar-standar TRIPs yang meliputi: Penambahan jangka waktu perlindungan paten; Memperluas lingkup teknologi yang dapat dipatenkan; Mendefinisikan kembali lingkup dari hak paten; Meningkatkan perlindungan terhadap merek terkenal; Mengatur mengenai penyewaan program komputer dan karya-karya audiovisual. ${ }^{35}$

\footnotetext{
${ }^{31} \mathrm{Ibid}$, hal. 26-28.

${ }^{32}$ Ibid, hal. 30-31.

${ }^{33}$ Ibid, hal. 35-36.

${ }^{34}$ Ibid, hal. 38.

${ }^{35}$ Ibid, hal. 40.
} 
Kerja sama regional di bidang Kekayaan Intelektual melengakapi sistem multilateral dengan dua cara yang umum: Harmonisasi hukum dan prosedur administrasi antar negara ASEAN berdasarkan TRIPS dan Perjanjian WTO.Mengadakan kerjasama di bidang pelatihan, dialog antar kewenangan, kegiatankegiatan penyadaran publik dan sektor swasta tentang Kekayaan Intelektual.

\section{Perjanjian Kerangka Kerja ASEAN (ASEAN Frame work Agreement)}

Perjanjian ini telah membangun sebuah proses kerja sama yang formal di antara negara-negara $A S E A N$ dengan tujuan yang mencakup: Memperkuat dan mengajukan kerjasama di bisang Kekayaan Intelektual, yang melibatkan lembaga-lembaga pemerintah, sektor swasta dan lembaga-lembaga profesional; Memperdalam pengaturan kerja sama antar anggota $A S E A N$ di bidang Kekayaan Intelektual, meningkatkan solidaritas $A S E A N$ dalam menddrong inovasi teknologi serta alih dan penyebaran teknologi; Menjajaki kemungkinan pendirian sistem paten $A S E A N$, termasuk kantor paten $A S E A N$; Menjajaki kemungkinan pendirian/ sistem merek $A S E A N$, termasuk kantor merek $A S E A N$; Mengadakan konsultasi mengenai perkembangan aturan Kekayaan Intelektual negara-negara $A S E A N$ dengan visi untuk menciptakan standar dan praktik $A S E A N$ yang konsisten dengan standar internasional. ${ }^{36}$

\section{Undang-Undang Nasional di Bidang Kekayaan Intelektual .}

Untuk mewujudkan perlindungan Kekayaan Intelektual di Indonesia, dengan membuat:

1. Undang-undang Republik Indonesia Nomor 28 Tahun 2014 Tentang Hak Cipta

2. Undang-undang Republik Indonesia Nomor 20 Tahun 2016 Tentang Merek Dan Indikasi Geografis

3. Undang-undang Republik Indonesia Nomor 13 Tahun 2016 Tentang Paten

4. Undang-undang Republik Indonesia Nomor 31 Tahun 2000 Tentang Desain Industri

5. Undang-undang Republik Indonesia Nomor 32 Tahun 2000 Tentang Desain Tata Letak Sirkuit Terpadu

6. Undang-undang Republik Indonesia Nomor 29 Tahun 2000 Tentang Perlindungan Varietas Tanaman

7. Undang-undang Republik Indonesia Nomor 30 Tahun 2000 Tentang Rahasia Dagang

\section{Prinsip-Prinsip Kekayaan Intelektual}

Prinsip-prinsip Kekayaan Intelektual adalah sebagai berikut :

1. Prinsip ekonomi. Dalam prinsip ekonomi, hak intelektual berasal dari kegiatan kreatif dari daya pikir manusia yang memiliki manfaat serta nilai ekonomi yang akan member keuntungan kepada pemilik hak cipta.

2. Prinsip keadilan. Prinsip keadilan merupakan suatu perlindungan hukum bagi pemilik suatu hasil dari kemampuan intelektual, sehingga memiliki kekuasaan dalam penggunaan hak atas Kekayaan Intelektual terhadap karyanya.

${ }^{36}$ Ibid, hal. 38. 
3. Prinsip kebudayaan. Prinsip kebudayaan merupakan pengembangan dari ilmu pengetahuan, sastra dan seni guna meningkatkan taraf kehidupan serta akan memberikan keuntungan bagi masyarakat, bangsa dan Negara.

4. Prinsip sosial. Prinsip sosial mengatur kepentingan manusia sebagai warga Negara, sehingga hak yang telah diberikan oleh hukum atas suatu karya merupakan satu kesatuan yang diberikan perlindungan berdasarkan keseimbangan antara kepentingan individu dan masyarakat/ lingkungan. ${ }^{37}$

\section{Objek, Hakekat dan Benda Tak Berwujud Kekayaan Intelektual}

Objek Kekayaan Intelektual adalah ciptaan, hasil buah pikiran, atau intelektualita manusia. Oleh sebab itu dinamakan Kekayaan Intelektual atau Intellectual property. Dimana karya-karya yang timbul atau lahir karena kemampuan daya pikir intelektual manusia yang di ekspriesikan kepada umum. Hakekat Kekayaan Intelektual merupakan hak-hak yang ada dalam Kekayaan Intelektual sebagian besar diterapkan dalam perdagangan barang dan jasa, sehingga makna (the subject matter) dari hak Kekayaan Intelktual mengelilingi dan mempengaruhi kehidupan sehari-hari dari tiap orang. Sehingga hakikat dari tatanan hak yang pada dasarnya bersifat pribadi (Privat) mempengaruhi aturan-aturan umum di dalam masyarakat.

Kekayaan Intelektual memiliki berbagai bentuk yang saling berbeda, tapi juga memiliki kemiripan tertentu. Kemiripan yang utama ialah perlindungan terhadap benda "tidak berwujud" (intangible things). Benda-benda ini disebut 'tidak berwujud' karena mereka merupakan gagasan, penemuan, tanda, dan informasi. Hal ini menempatkan Kekayaan Intelektual dalam posisi yang berbeda dengan hak milik atas benda 'berwujud' yang mana berfungsi sebagai titel atas suatu obyek yang berwujud/berbentuk. Sedangkan Kekayaan Intelektual, pada saat merupakan bentuk tidak berwujud juga sekaligus mengandung hak-hak yang tidak berwujud. Dengan kata lain, hak milik yang tidak berwujud dikandung dalam obyek berwujud (In the other words, the intangible property is embodied in the tangible object). Keadaan semacam ini melahirkan konsekuensi hukum.

\section{Peran Kekayaan Intelektual di Indonesia}

Peranan Kekayaan Intelektual di Indonesia sangatlah bermanfaat, antara lain:

a. Mengangkat harkat dan martabat manusia dan masyarakat Indonesia.

b. Meningkatkan produktivitas, mutu, dan daya saing produk ekonomi Indonesia.

c. Membantu tercapainya alih teknologi dari negara maju ke negara berkembang

d. Menciptakan iklim perdagangan dan investasi yang baik di Indonesia.

e. Mendukung perkembangan dunia usaha yang kompetitif dan spesifik dalam dunia usaha.

f. Meningkatkan karya intelektual dalam negeri yang berorientasi ekspor dan bernilai komersial.

g. Mempromosikan sumber daya sosial dan budaya yang dimiliki.

h. Memberikan reputasi internasional untuk ekspor produk lokal yang berkarakter dan memiliki tradisi budaya daerah.

i. Membantu perkembangan ilmu dan teknologi serta ekonomi negara lain dengan fasilitas lisensi.

${ }^{37}$ https://www.duniadosen.com, Op. Cit., diakses 6 November 2020, pkl 19.48 WIB. 


\section{A. Pelaksanaan Perlindungan Hukum Kekayaan Intelektual Bagi Pembangunan Ekonomi Indonesia.}

Pembangunana ekonomi suatu negara sangat berkaitan erat dengan perlindungan Kekayaan Intelektualnya. Semakin terbuka sistem perekonomian suatu negara, maka perlindungan Kekayaan Intelektual akan memainkan peranannya dalam mendukung pertumbuhan ekonomi negara tersebut. Untuk itu pentingnya pendekatan yang seimbang terhadap sistem kekayaan intelektual global untuk pelindungan, pemajuan, dan pemanfaatan Kekayaan Intelektual bagi pembangunan ekonomi nasional.

Indonesia merupakan salah satu negara yang telah meratifikasi pembentukan World Trade Organization (WTO) melalui Undang-Undang No. 7 Tahun 1994. Konsekwensi Indonesia harus melaksanakan kewajiban untuk menyesuaikan peraturan perundang-undangan nasionalnya dengan ketentuan WTO, termasuk yang berkaitan Agreement onTrade Related Aspects of Intellectual Property Rights. ${ }^{38}$ Tujuan utama persetujuan TRIPs-WTO adalah untuk meningkatkan perlindungan yang efektif dan memadai terhadap Kekayaan Intelektual dan untuk menjamin bahwa prosedur langkah-langkah penegakan hukum Kekayaan Intelektual itu sendiri tidak menjadi hambatan terhadap perdagangan. ${ }^{39}$ Perjanjian mengenai Trade Related Aspects Of IntellectualProperty Rights (TRIPs) atau aspek Perdagangan Kekayaan Intelektual merupakan salah satu perjanjian utama yang dihasilkan oleh perundingan Uruguay Round yang telah berjalan dari tahun 1986 hingga 1994. Perjanjian putaran Uruguay menentukan jenis-jenis hak atas kepercayaan intelektual yang termasuk dalam perjanjian. Hak tersebut menyangkut: copyrights atau hak cipta dan hak-hak yang terkait, trade marks atau merek dagang, geographical indication, industrial design, paten, topografi mengenaiintegrated circuit undisclosed information atau rahasia dagang. ${ }^{40}$

Kekayaan Intelektual harus dilindungi di Indonesia, antara lain dengan membentuk Undang-Undang tentang Kekayaan Intelektual. Pembentukan UndangUndang ini dimaksudkan untuk memberikan perlindungan hukum yang memadai terhadap Kekayaan Intelektual, yang pada gilirannya akan mempercepat pembangunan nasional serta sekaligus mendorong lahirnya berbagai kreasi dan inovasi di bidang Kekayaan Intelektual. Pada dasarnya ada dua jenis hak dalam Kekayaan Intelektual yang harus dilindungi, yakni hak ekonomi (economic right) dan hak moral (moral right). Hak ekonomi adalah hak yang dimiliki pemegang hak untuk mendapatkan keuntungan ekonomi dari hak ekslusif yang dimilikinya. Sedangkan hak moral adalah hak personal di mana seorang inventor untuk disebutkan namanya atas suatu karya intelektualnya.

Perlindungan hukum Kekayaan Intelektual didasarkan pada Pancasila dan Undang-Undang Dasar 1945 (UUD 1945). Hal ini sesuai dengan pendapat dari Oemar Senoadji ${ }^{41}$ dan Padmo Wahyono ${ }^{42}$ yang menyatakan bahwa sumber hukum untuk konteks Republik Indonesia adalah Pancasila dan UUD 1945. Tujuan negara Indonesia sebagaimana tertulis pada alinea keempat Pembukaan UUD 1945 adalah: “ ... membentuk suatu pemerintah negara Indonesia yang melindungi segenap bangsa Indonesia dan seluruh tumpah darah Indonesia dan untuk memajukan kesejahteraan

\footnotetext{
38 Afrillyanna Purba. Gazalba Saleh, Adriana Krisnawati. Trips-WTO dan Hukum HKI Indonesia, Jakarta: PT Rineka Cipta, hal. 1.

${ }^{39}$ Ibid, hal. 2.

${ }^{40}$ Kartadjoemana, HS, GATT, WTO dan Hasil Uruguay Round, Jakarta: Ul-Press, 1997, hal. 252- 253.

${ }^{41}$ Oemar Senoadji, Peradilan Bebas Negara Hukum, Jakarta: Erlangga, 1980, hal. 24-58.

${ }^{42}$ Padmo Wahyono, Konsep Yuridis Negara Hukum Indonesia, Makalah, September, 1988, hal. 4.
} 
umum, mencerdaskan kehidupan bangsa, dan ikut melaksanakan ketertiban dunia yang berdasarkan kemerdekaan, perdamaian abadi dan keadilan sosial...

Sistem perekonomian nasional tidak hanya berorientasi pada pasar di dalam negeri, namun juga berorientasi terhadap pasar internasional. Perkembangan internasional memberikan pengaruh terhadap perkembangan hukum nasional, antara lain terjadinya keterkaitan antara perkembangan hukum internasional dengan hukum nasional, terciptanya arena transnasional dalam praktek hukum yang bersumber dari kekuatan-kekuatan dan logika yang bekerja dalam bidang ekonomi ${ }^{43}$ Keikutsertaan Indonesia menjadi anggota World Trade Organization (WTO) adalah dalam rangka memenuhi tujuan negara untuk ikut melaksanakan ketertiban dunia yang berdasarkan kemerdekaan, perdamaian abadi dan keadilan sosial, khususnya di bidang ekonomi (perdagangan internasional). Dalam bidang Kekayaan Intelektual, melalui keikutsertaan Indonesia dalam keanggotaan WTO, mewajibkan Indonesia untuk melaksanakan ketentuan Agreement on Trade Related Aspect of Intellectual Property Rights (Persetujuan TRIPS/WTO), yang mengatur aspek-aspek Kekayaan Intelektual dihubungkan dengan perdagangan. ${ }^{44}$

Dalam pembentukan hukum yang mengatur Kekayaan Intelektual harus tetap memiliki orientasi pada kepentingan nasional, walaupun ketentuan dalam Persetujuan TRIPs/WTO tidak dapat diabaikan.Untuk itu dalam pembentukan peraturan perundang-undangan seyogyanya mengacu pada falsafah Pancasila yang mengedepankan keseimbangan antara hak-hak individual dan hak masyarakat (komunal), prinsip-prinsip hukum yang terkandung dalam UUD 1945 dan realitas sosial bangsa Indonesia. ${ }^{45}$ Perlindungan hukum Kekayaan Intelektual di Indonesia harus berpegang pada teori keadilan yang berdasarkan pada Pancasila. Hal ini dipertimbangkan atas dasar bahwa ilmu pengetahuan yang ingin dikembangkan di Indonesia harus berdasarkan pada nilai-nilai keTuhanan dan berpuncak pada nilai-nilai keadilan sosial bagi seluruh rakyat Indonesia. ${ }^{46}$ Untuk itu berdasarkan prinsip-prinsip filsafat Pancasila, dalam sistem perlindungan Kekayaan Intelektual harus berlandaskan pada prinsip-prinsip sebagai berikut: Prinsip kemaslahatan manusia atau prinsip kemanusiaan; Prinsip keseimbangan kepentingan individu dan masyarakat; Prinsip nasionalisme; Prinsip keadilan sosial dan Prinsip pengembangan ilmu pengetahuan dan teknologi (iptek) tidak bebas nilai (iptek berdasarkan nilai-nilai Pancasila).

Prinsip kemaslahatan manusia atau prinsip kemanusiaan diwujudkan dalam bentuk perlindungan hak-hak asasi manusia yang salah satunya diwujudkan melalui perlindungan, Kekayaan Intelektual dimana manusia beradab hidup dengan sumber daya cipta, rasa, karsa dan keyakinan sebagai landasan bertindak sesuai nilai-nilai hidup manusiawi.

\footnotetext{
43 Satjipto Rahardjo, Pembangunan Hukum di Indonesia dalam Konteks Global, Makalah pada Pertemuan Dosen Pengajar Sosiologi Hukum Se Jawa Tengah dan Daerah Istimewa Yogyakarta, Universitas Muhammadiyah Solo (UMS), Surakarta, Tanggal 5-6 Agustus 1996.

44 Undang-Undang Nomor 7 Tahun 1994 Tentang Pengesahan Agreement Establishing the Workd Trade Organization (Persetujuan Pembentukan Organisasi Perdagangan Dunia). Perlindungan Hak Desain Industri diatur secara khusus dalam Pasal 25 dan Pasal 26 Persetujuan TRIPS/WTO.

${ }^{45}$ Candra Irawan, Politik Hukum Hak Kekayaan Intelektual Indonesia, Bandung: Mandar Maju, 2011, hal. 22.

${ }^{46}$ Slamet Sutrisno, Filsafat dan Ideologi Pancasila, Yogyakarta: Andi, 2006, hal. 71.
} 
Prinsip keseimbangan kepentingan individu dan masyarakat diwujudkan melalui pengaturan sistem perlindungan Kekayaan Intelektual yang menghargai karya intelektual seseorang dengan pemberian hak eksklusif, namun tetap menjaga kepentingan masyarakat banyak, dengan memungkinkan pencabutan hak eksklusif tersebut apabila dalam pelaksanaanya akan berdampak merugikan masyarakat.

Prinsip nasionalisme dapat diwujudkan dengan pengaturan sistem perlindungan Kekayaan Intelektual yang mengutamakan kepentingan nasional dengan tetap berpegang pada ketentuan perjanjian internasional yang mengatur Kekayaan Intelektual.

Prinsip keadilan sosial diwujudkan melalui keseimbangan antara hak dan kewajiban dalam pengaturan sistem perlindungan Kekayaan Intelektual, yang memperhatikan juga keseimbangan antara cinta kemajuan dan pembangunan yang selaras serasi dengan nilai-nilai luhur bangsa Indonesia untuk mencapai cita-cita masyarakat adil makmur, material dan spiritual, yang merata bagi seluruh rakyat Indonesia.

Prinsip pengembangan ilmu dan teknologi yang berkaitan dengan perlindungan Kekayaan Intelektual berdasarkan Pancasila dengan memperhatikan seluruh nilai-nilai yang terkandung dalam Pancasila yakni sila keTuhanan, kemanusiaan, persatuan, kerakyatan, dan keadilan sosial. ${ }^{47}$

Tujuan pembangunan hukum perlindungan Kekayaan Intelektual yang kompleks ini hanya mungkin dapat diwujudkan dengan baik dan nyata jika proses hukum berlangsung dengan baik dan stabil. Proses yang baik dan stabil ini hanya mungkin berlangsung jika setiap komponen hukum berfungsi dengan baik dan benar. Dengan penekanan pada proses dan fungsi dari seluruh komponen sistem hukum, maka satusatunya pendekatan yang dapat memenuhi kebutuhan ini adalah pendekatan sistem atau teori sistem hukum. Menurut Lawrence M. Friedman, sistem hukum merupakan suatu sistem yang meliputi substansi, struktur, dan budaya (kultur) hukum. Dalam sistem hukum perlindungan, struktur hukumnya mencakup institusi penegakan hukum beserta aparatnya yang menangani bidang Kekayaan Intelektual. Peran Kekayaan Intelektual dalam persaingan usaha di Indonesia tidak dapat dikesampingkan begitu saja keberadaannya. Keberadaan rezim hukum Kekayaan Intelektual dan Hukum Persaingan Usaha hendaknya dipandang sebagai ketentuan hukum yang bersifat komplementer atau saling mengisi untuk keharmonisan sistem hukum nasional Indonesia. ${ }^{48}$

Di Indonesia perlindungan Kekayaan Intelektual juga dibutuhkan antara lain: Sejalan dengan ratifikasi Indonesia pada perjanjian-perjanjian internasional, perkembangan teknologi, industri, dan perdagangan yang semakin pesat; dalam rangka menciptakan iklim persaingan usaha yang jujur serta memperhatikan kepentingan masyarakat pada umumnya; agar pemegang Kekayaan Intelektual berhak atas dasar ketentuan undang-undang melakukan upaya hukum mengajukan tuntutan apabila haknya dilanggar, baik tuntutan perdata maupun pidana.

Disamping itu, alasan mengapa Kekayaan Intelektual harus dilindungi adalah:

\footnotetext{
${ }^{47}$ Noor M.S. Bakry, Pancasila Yuridis Kenegaraan, Yogyakarta: Liberty, 2003, hal. 163-165.

48 Peraturan KPPU RI No. 2 Tahun 2009 Tentang Pengecualian Penerapan UU No. 5 Tahun 1999 Tentang Larangan Praktek Monopoli dan Persaingan Usaha Tidak Sehat Terhadap Perjanjian Yang Berkaitan Dengan Hak Atas kekayaan Intelektual, hal. 4.
} 
1. Perhatian masyarakat terhadap Kekayaan Intelektual makin meningkat

2. Memiliki nilai-nilai moral (moral values) dan memiliki nilai ekonomi.

3. Indonesia sebagai negara yang memiliki keanekaragaman suku/etnik dan budaya serta kekayaan di bidang seni, sastra dan budaya serta ilmu pengetahuan dengan pengembangannya yang lahir dari keanekaragaman tersebut.

4. Sebagai insentif bagi inventor, desainer dan pencipta dengan memberikan hak khusus untuk mengkomersialkan hasil kreatifitasnya.

5. Mengurangi peluang dalam melakukan pelanggaran dalam membuat hasil karya.

6. Mendorong kegiatan penelitian dan pengembangan untuk menghasilkan penemuan baru di berbagai bidang teknologi.

7. Mempercepat pertumbuhan indrustri, menciptakan lapangan kerja baru, mendorong pertumbuhan ekonomi, meningkatkan kualitas hidup manusia yang memberikan kebutuhan masyarakat secara luas.

Manfaat Kekayaan Intelektual bagi pembangunan di Indonesia pasca Perjanjian TRIPs adalah: Meningkatkan posisi perdagangan dan investasi; Mengembangkan teknologi; Mendorong perusahaan untuk dapat bersaing secara internasional; Membantu komersialisasi inventoran dan inovasi secara efektif; Mengembangkan sosial budaya; Menjaga reputasi internasional untuk kepentingan ekspor ${ }^{49}$. Manfaat utama perlindungan Kekayaan Intelektual bagi Indonesia: Membantu menarik minat para investor asing masuk ke Indonesia; Meningkatkan pertumbuhan ekonomi Indonesia di masa yang akan datang; Mengembangkan teknologi, inovasi dan kreasi ${ }^{50}$.

Kekayaan Intelektual harus mendapat perlindungan sepanjang tidak bertentangan dengan peraturan perundang-undangan yang berlaku, ketertiban umum, agama, atau kesusilaan. Dengan adanya jaminan terhadap perlindungan Kekayaan Intelektual, maka diharapkan masyarakat akan semakin bergairah untuk menghasilkan kreasi dibidang Kekayaan Intelektual. Dengan demikian dapat meningkatkan kesejahteraannya sekaligus meningkatkan perekonomian dan pendapatan negara.

\section{B. Permasalahan Pelaksanaan Perlindungan Hukum Kekayaan Intelektual Bagi Pembangunana Ekonomi Indonesia.}

Permasalahan pelaksanaan perlindungan hukum Kekayaan Intelektual dalam rangka meningkatkan pembangunana ekonomi Indonesia tidak terlepas dari sudut pandang Terhadap Kekayaan Intelektual itu sendiri. Di Indonesia penerapan perlindungan hukum terhadap Kekayaan Intelektual adalah masalah yang rumit. Masih ada yang berpendapat bahwa manfaat dari perlindungan hukum Kekayaan Intelektual yang dilakukan justru hanya akan dinikmati oleh negara-negara pengekspor Kekayaan Intelektual. Negara berkembang seperti Indonesia biasanya hanya berperan sebagal konsumen, bukan produsen Kekayaan Inteletual, sehingga mereka tidak merasa harus melindungi secara ketat. Alasan lain bahwa perlindungan hukum Kekayaan Intelektual dapat menimbulkan, antara lain: Hak monopoli terbatas dari sistim Kekayaan Intelektual biaya tinggi; Perusahaan-perusahaan yang memiliki Kekayaan Intelektual tidak mengeksploitasi karya intelektual mereka secara penuh kepada masyarakat karena mereka menyimpan Kekayaan Intelektual tersebut untuk kepentingan bisnis; Sistim Kekayaan Intelektual dapat menghambat penyebaran ilmu pengetahuan.

${ }^{49}$ Tim Lindsey, dkk, Asian Law Group Pty.Ltd, Op. Cit., hal.78.
${ }^{50}$ Ibid, hal. 80. 
Permasalahan-permasalahan di atas dipengaruhi berbagai faktor, antara lain: Hambatan yuridis dan non yuridis. Pertama, Hambatan yuridis yang terjadi adalah implementasi hukum yang tidak efektif dalam merangsang perkembangan teknologi untuk penerapan teknologi. Dalam hal ini fungsi hukum sebagai sarana untuk melakukan perubahan di dalam masyarakat tidak berjalan dengan baik walau hukum positif tersebut merupakan sandaran negara untuk dapat mewujudkannya kebijaksanannya. Tujuan ideal dari pembentukan Undang-undang di bidang Kekayaan Intelektual diharapkan dapat merangsang perkembangan teknologi sehingga dapat meningkatkan perkembangan ekonomi dan pada akhirnya meningkatkan pembangunan nasional. Kenyataan dilapangan sering tidak sesuai dengan teori.

Ada beberapa faktor yang dapat mempengaruhi tidak efektifnya hukum positif, salah satu faktor yang penting adalah ketidakserasian antar elemen dalam sistem hukum Indonesia. Menurut pendapat Friedman, ada tiga elemen utama dalam sistem hukum, yaitu: 1). Substansi dan norma-norma, 2). Aparatur atau elemen penegak hukum 3). Budaya hukum masyarakatnya. Khusus dalam konteks Kekayaan Intelektual pada umumnya, kesenjangan antar elemen sistem hukum itu begitu terasa, karena memang norma ini merupakan legal transplant yang membawa serta struktur sosial masyarakat di negara- negara barat. ${ }^{51}$ Kedua, Faktor non yuridis. Hal ini berkaitan dengan budaya hukum dimana keterkaitan cara pandang masyarakat terhadap sistem hukum tersebut dan kemauan melaksanakannya. Hambatan ini dikaji melalui budaya hukum yaitu tentang sikap dalam mengetahui, memahami dan menjalankan hukum tersebut. Bangsa Indonesia sebagai negara berkembang mempunyai kekhasan dalam karakteristik masyarakatnya. Masyarakat di Indonesia merupakan masyarakat komunal yang menempatkan kepentingan bersama lebih tinggi dari kepentingan individu, meskipun itu tidak berarti pula bahwa individu kehilangan hak-haknya.

Pandangan atau sikap apriori terhadap perlindungan Kekayaan Intelektual seharusnya tidak terjadi sebab bersikap apriori terhadap keberadaan Kekayaan Intelektual hanya karena dampak negatif yang ditimbulkan adalah tindakan yang kurang bijaksana. Ada tiga argumen yang mendukung pernyataan ini: Pertama, kerugian yang ditimbulkan akibat penerapan sistim Kekayaan Intelektual adalah bersifat sementara dan berlangsung dalam jangka pendek. Kedua, menolak kehadiran Kekayaan Intelektual karena dampak negatifnya juga dapat mendatangkan kerugian bagi Indonesia. Alasan yang dapat diajukan adalah karena seluruh negara anggota WTO sepakat menerapkan Kekayaan Intelektual dengan segala konsekuensinya. Ketiga, Pembahasan tentang ketidak setujuan terhadap keberadan Kekayaan Intelektual adalah tindakan yang telambat dan sia-sia. ${ }^{52}$

Alasan lainnya adalah Indonesia telah memiliki komitmen yang sangat kuat terhadap perlindungan Kekayaan Intelektual hal ini dapat dilihat dengan: Dibentuknya Undang-Undang Nasional di bidang Kekayaan Intelektual, yaitu tentang: Hak Cipta, Merek Dan Indikasi Geografis, Paten, Desain Industri, Desain Tata Letak Sirkuit Terpadu, Perlindungan Varietas Tanaman dan Rahasia Dagang; Ikut ambil bagian dalam Persetujuan/Perjanjian Kerangka Kerja ASEAN (ASEAN Frame work Agreement) dan Asia-Pacific Economic Cooperation (APEC) dalam agenda kerja Osaka; Menjadi anggota Organisasi Perdagangan Dunia World Trade Organization

\footnotetext{
${ }^{51}$ Lawrence M. Friedmann, The Legal System: A Social Science Perspective, New York: Russel Sage Foundation, 1975, hal. 11-16.

52 Ibid, hal. 83.
} 
(WTO) menyiratkan bahwa Indonesia secara otomatis terikat pada TRIPs; Meratifikasi World Intellectual Property Organization (WIPO)

Namun demikian dalam prakteknya perlindungan hukum terhadap Kekayaan Intelektual masih menimbulkan berbagai permasalahan.

Permasalahan-permasalahan tersebut dapat diatasi dengan baik dan nyata jika proses hukum berlangsung dengan baik dan stabil. Proses yang baik dan stabil ini hanya mungkin berlangsung jika setiap komponen hukum berfungsi dengan baik dan benar. Dengan penekanan pada proses dan fungsi dari seluruh komponen sistem hukum, maka satu-satunya pendekatan yang dapat memenuhi kebutuhan ini adalah pendekatan sistem atau teori sistem hukum. Menurut Lawrence M. Friedman, sistem hukum merupakan suatu sistem yang meliputi substansi, struktur, dan budaya (kultur) hukum. Dalam sistem hukum perlindungan Kekayaan Intelektual, struktur hukumnya mencakup institusi penegakan hukum beserta aparatnya yang menangani bidang Kekayaan Intelektual.

Kekayaan Intelektual harus dilindungi sepanjang tidak bertentangan dengan peraturan perundang-undangan yang berlaku, ketertiban umum, agama, atau kesusilaan. Apabila terjadi pelanggaran, maka pemegang Kekayaan Intelektual dapat menuntut secara perdata dan/atau pidana pihak yang melakukan pelanggaran. Dengan adanya jaminan terhadap perlindungan Kekayaan Intelektual maka diharapkan para pelaku Kekayaan Intelektual (inventor, pencipta, pendesain dan sebagainya) semakin bergairah untuk menghasilkan karya dibidang Kekayaan Intelektual. Upaya-upaya yang dilakukan, antara lain: Pemerintah berperan aktif untuk mensosialisasikan secara terus menerus terkait Kekayaan Intelektual kepada masyarakat dan pelaku usaha, baik yang ada di dalam negeri; Melakukan revisi terhadap peraturan-peraturan dibidang Kekayaan Intelektual dengan memperhatikan kepentingan pelaku usaha/ekonomi dengan tetap memperhatikan kepentingan nasional diantaranya adalah untuk membangun industri yang berbasis pada hasil kreatifitas dan inovasi bangsa Indonesia sendiri; Revisi peraturan Kekayaan Intelektual dilakukan dengan mengakomodir masukan-masukan masyarakat; Harus memperhatikan perkembangan Kekayaan Intelektual dibidang Industri di masa yang akan datang khususnya menghadapi perdagangan internasional; Revisi harus mengakomodir kepentingan internasional karena Indonesia adalah bagian dari masyarakat internasional; Untuk mendukung sistem, dibutuhkan dukungan IT yang memadai; Perlu kerjasama antara Departemen Perdagangan dengan Kementerian Hukum dan Hak Asasi Manusia (Direktorat Jenderal Kekayaan Intelektual) untuk memetakan dan memberikan pelayanan khusus di bidang Kekayaan Intelektual; Kerja sama dengan sejumlah perguruan tinggi di tanah air perlu ditindaklanjuti dengan membuat rencana pemanfaatan karya intelektual Dosen dan Mahasiswa melalui pendirian pusat pengelolaan Kekayaan Intelektual (klinik Kekayaan Intelektual) di Perguruan Tinggi; Penegak hukum harus benar-benar serius dalam mengawasi, memproses dan menyelesaikan setiap pelanggaran yang terjadi dan memberikan hukuman yang setimpal sehingga terwujud kepastian hukum. Dengan adanya sanksi yang tegas dapat menimbulkan efek jera bagi yang melakukan pelanggaran; Perlu dipikirkan untuk menjadikan Kekayaan Intelektual sebagai salah satu mata kuliah wajib yang tercantum dalam kurikulum nasional, tidak hanya di Fakultas Hukum, tetapi juga di fakultas-fakultas eksakta. Dengan demikian perlindungan hukum Kekayaan Intelektual dapat memajukan ekonomi di Indonesia, sehingga memberikan kesejahteraan bagi seluruh bangsa Indonesia. 


\section{KESIMPULAN}

Pembangunan ekonomi suatu negara berkaitan erat dengan perlindungan Kekayaan Intelektualnya. Semakin tinggi penghargaan negara terhadap Kekayaan Intelektual, akan merangsang pertumbuhan ekonomi. Kekayaan intelektual adalah hak yang timbul dari hasil olah pikir yang menghasilkan suatu produk atau proses yang bermanfaat untuk manusia. Pada intinya kekayaan intelektual adalah hak untuk menikmati secara ekonomis hasil dari suatu kreativitas intelektual. Indonesia memiliki komitmen yang sangat kuat terhadap perlindungan Kekayaan Intelektual baik yang bersifat nasional, regional maupun internasional. Hal ini dapat dilihat dengan: Dibentuknya Undang-Undang Nasional di bidang Kekayaan Intelektual, yaitu tentang: Hak Cipta, Merek Dan Indikasi Geografis, Paten, Desain Industri, Desain Tata Letak Sirkuit Terpadu, Perlindungan Varietas Tanaman dan Rahasia Dagang; Ikut ambil bagian dalam Persetujuan/Perjanjian Kerangka Kerja ASEAN (ASEAN Frame work Agreement) dan Asia-Pacific Economic Cooperation (APEC) dalam agenda kerja Osaka; Menjadi anggota Organisasi Perdagangan Dunia World Trade Organization (WTO) menyiratkan bahwa Indonesia secara otomatis terikat pada TRIPs; Meratifikasi World Intellectual Property Organization (WIPO). Pembentukan hukum yang mengatur Kekayaan Intelektual harus tetap memiliki orientasi pada kepentingan nasional dan mengakomodir internasional. Perlindungan hukum Kekayaan Intelektual di Indonesia berpegang pada teori keadilan yang berdasarkan pada Pancasila. Dengan prinsip-prinsip: Kemaslahatan manusia/kemanusiaan; Keseimbangan kepentingan individu dan masyarakat; Nasionalisme; Keadilan sosial dan Pengembangan ilmu pengetahuan dan teknologi (iptek) tidak bebas nilai (berdasarkan nilai-nilai Pancasila).

Meskipun telah dibentuk dan diberlakukan berbagai peraturan yang mengatur bidang Kekayaan Intelektual, masih terdapat banyak permasalahan-permasalahan, dipengaruhi berbagai faktor, antara lain: yang berkaitan dengan Substansi, struktur, dan budaya (kultur) hukum. Perlindungan Kekayaan Intelektual dapat diwujudkan dengan baik dan nyata jika setiap komponen hukum berfungsi dengan baik dan benar, meliputi: Substansi, struktur, dan budaya (kultur) hukum.

\section{SARAN}

1. Sosialisasi terkait pentingmya perlindungan Kekayaan Intelektual hendaklah dilakukan secara terus menerus kepada masyarakat dan pelaku usaha.

2. Melakukan perbaikan-perbaikan/pembenahan menyangkut: Substansi, struktur dan budaya (kultur) hukum.

3. Meningkatkan kerjasama dengan pihak terkait.

4. Perubahan dengan mempertimbangkan, antara lain: Perlindungan kepentingan nasional, memperhatikan ketentuan-ketentuan internasional dan mengakomodir masukan-masukan masyarakat.

\section{DAFTAR PUSTAKA}

\section{Buku}

Braithwaite, John dan Peter Drahos, Global Business Regulation, New York: Cambridge University Press, 2000.

Candra Irawan, Politik Hukum Hak Kekayaan Intelektual Indonesia, Bandung: Mandar Maju, 2011. 
Ditjen kekayaan intelektual, Buku Panduan Hak Kekayaan Intelektual, 2006, hal. 7.

Friedman, M, Lawrence, Legal Cultur and the Welfare State: Law and Society-An Introduction, Cambridge, Massachusetts, London: Harvard University Press, 1990.

, The Legal System: A Social Science Perspective, New York: Russel Sage Foundation, 1975.

Kartadjoemana, HS, GATT, WTO dan Hasil Uruguay Round,Ul-Press, Jakarta, 1997.

Noor M.S. Bakry, Pancasila Yuridis Kenegaraan, Yogyakarta: Liberty, 2003.

Oemar Senoadji, Peradilan Bebas Negara Hukum, Jakarta: Erlangga, 1980.

Padmo Wahyono, Konsep Yuridis Negara Hukum Indonesia, Makalah, September, 1988.

Pipin Syarifin \& Dedah Jubaedah, Peraturan Hak Kekayaan Intelektual di Indonesia, Bandung: Pustaka Bani Quraisy, 2004.

Purba, Afrillyanna, Gazalba Saleh, Adriana Krisnawati. Trips-WTO dan Hukum HKI Indonesia. PT Rineka Cipta, Jakarta.

Ranti Fauza Mayana, Perlindungan Desain Industri di Indonesia, Jakarta: Gramedia Widiasarana Indonesia, 2004.

Slamet Sutrisno, Filsafat dan Ideologi Pancasila, Yogyakarta: Andi, 2006.

Soerjono Soekanto, Penelitian Hukum Normatif, Jakarta: PT Raja Grafindo Persada, 2003.

Suhasril dan Mohammad Taufik Makarao, Hukum Larangan Praktik Monopoli dan Persaingan Usaha Tidak Sehat di Indonesia, Bogor: Ghalia Indonesia, 2010.

Sutedi, A, Hak Atas Kekayaan Intelektual, Jakarta: Sinar Grafika, 2009.

Tim Lindsey, dkk, Asian Law Group Pty.Ltd, Hak Kekayaan Intelektual Suatu Pengantar, Bandung: PT. Alumni, 2011.

\section{Peraturan Perundang-Undangan}

Undang-Undang Nomor 7 Tahun 1994 Tentang Pengesahan Agreement Establishing the Workd Trade Organization (Persetujuan Pembentukan Organisasi Perdagangan Dunia).

Undang-undang Nomor 31 Tahun 2000 Tentang Desain Industri.

Undang-undang Nomor 32 Tahun 2000 Tentang Desain Tata Letak Sirkuit Terpadu.

Undang-undang Nomor 29 Tahun 2000 Tentang Varietas Tanaman.

Undang-undang Nomor 30 Tahun 2000 Tentang Rahasia Dagang.

Undang-undang Nomor 28 Tahun 2014 Tentang Hak Cipta.

Undang-undang Nomor 20 Tahun 2016 Tentang Merek dan Indikasi Geografis.

Undang-undang Nomor 13 Tahun 2016 Tentang Paten.

Instruksi Presiden RI Nomor 6 Tahun 2009 Tentang Pengembangan Ekonomi Kreatif. Kategori ke 15 adalah kuliner. 
Peraturan KPPU RI No. 2 Tahun 2009 Tentang Pengecualian Penerapan UU No. 5 Tahun 1999 Tentang Larangan Praktek Monopoli dan Persaingan Usaha Tidak Sehat Terhadap Perjanjian Yang Berkaitan Dengan Hak Atas kekayaan Intelektual.

Cita Citrawinda,dkk, Naskah Akademik Rancangan Undang-undang Tentang Desain Industri, Pusat Perencanaan Pembangunan Hukum Nasional Badan Pembinaan Hukum Nasional Kementerian Hukum dan Hak Asasi Manusia.

\section{Makalah/Karya Ilmiah/ Buletin}

Rajagukguk, Erman, "Globalisasi Hukum dan Kemajuan Teknologi: Implikasinya Bagi Pendidikan Hukum dan Pembangunan Hukum Indonesia, ” pidato pada Dies Natalis Universitas Sumatera Utara Ke-44, Medan 20 Nopember 2001.

Satjipto Rahardjo, Pembangunan Hukum di Indonesia dalam Konteks Global, Makalah pada Pertemuan Dosen Pengajar Sosiologi Hukum Se Jawa Tengah dan Daerah Istimewa Yogyakarta, Universitas Muhammadiyah Solo (UMS), Surakarta, Tanggal 5-6 Agustus 1996.

Buletin Informasi dan Keragaman HKI yang diterbitkan oleh Direktorat Jenderal Hak Kekayaan Intelektual (“Ditjen HKI”), Vol. V/No.3/Juni 2008, hal. 11.

\section{Internet}

https://www.duniadosen.com/hak-atas-kekayaan-intelektual-haki/, diakses 5 November 2020, pkl 07.01 WIB.

https://www.hukumonline.com/klinik/detail/ulasan/cl3290/dasar-hukum-perubahanistilah-haki-menjadi-hki--kemudian-ki/, diakses 5 November 2020, pkl 07.01 WIB. 